\title{
Effects of Reflexology Massage on Hair Regrowth After Chemotherapy-induced Alopecia Among Women with Cancer: A Randomised Clinical Trial
}

\section{Refleksoloji Masajının Kanser Kadınlarında Kemoterapiye Bağlı Alopesi Sonrası Saçların Uzamasına Etkisi: Randomize Bir Klinik Çalışma}

\section{(i) Haleh GHAVAMI, iD Leyla ARJOMAND, iD Moloud RADFAR, iD Hamid Reza KHALKHALİ}

Urmia University of Medical Sciences, Nursing, Urmia, İran

\begin{abstract}
Objective: Chemotherapy-induced alopecia (CIA) is a common unwanted effect related to anti-neoplastic agents. Due to potential CIA, some patients with cancer consider refusing treatment. It negatively affects a patient's perception of appearance and sexuality. This study aimed to determine the effectiveness of reflexology massage on hair regrowth after CIA.
\end{abstract}

Methods: This randomised clinical trial was conducted in 60 women with cancer with full alopecia due to chemotherapy. They were divided randomly into two groups: the experimental and control groups. The patients in the experimental group received reflexology massage for $15 \mathrm{~min}, 3$ times daily (per $8 \mathrm{~h}$ ), for 3 months. Those in the control group only received treatment as usual and routine health care. Data were obtained from the patient information and hair measurement forms. Couliss Vernier was used for hair regrowth measurement. The minimum and maximum hair lengths were measured thrice monthly after intervention started in both groups.

Results: Considering baseline full alopecia in both groups, hair regrowth in the experimental group significantly improved compared with the control group $(\mathrm{p}<0.001)$.

Conclusion: In women with CIA, reflexology massage can improve hair regrowth after chemotherapy. This study may be added as evidence to the use of reflexology as a nonpharmacologic symptom management technique.

Keywords: Alopecia, cancer, chemotherapy, hair, reflexology

\section{ÖZ}

\begin{abstract}
Amaç: Kemoterapiye bağlı alopesi (KBA) anti-neoplastik ajanların yaygın olan yan etkisidir. Potansiyel KBA'nın etkisi o kadar derin ki, bazı kanserli hastalar tedaviyi reddediyorlar. KBA, hastanın görünüm algısı ve cinselliğini olumsuz etkiler. Bu çalışmanın amacı, refleksoloji masajının KBA sonrası saç uzaması üzerine etkisini belirlemekti.
\end{abstract}

Yöntemler: Bu randomize klinik çalışma, KBA kanserli 60 kadın üzerinde gerçekleştirildi. Hastalar rastgele yöntemi ile iki gruba ayrildılar; deney grubu ve kontrol grubu. Deney grubundaki örnekler, 3 ay boyunca her gün 15 dakika, günde $3 \mathrm{kez}$ (8 saatte bir) refleksoloji masajı aldılar. Kontrol grubu, tedavilerini sadece rutin, sağlık hizmetlerini normal şekilde aldılar. Veriler hasta bilgi formundan ve saç ölçüm formundan elde edildi. Saç uzama ölçümü için Couliss Vernier kullanıldı. Müdahalenin başlamasından sonra her ay minimum ve maksimum saç uzunlukları her iki grupta 3 kez ölçüldü.

Bulgular: Çalışmanın iki grubunda başlangıçtaki tam alopesi göz önüne alındığında, çalışmanın sonunda deney grubu kadınlarda saçların yeniden uzaması, kontrol grubuna göre anlamlı olarak $\operatorname{artmiştır~}(\mathrm{p}<0,001)$.

Sonuç: KBA’sı olan kadınlar için, refleksoloji masajı kemoterapiden sonra saçlarının yeniden uzamasını artırabilir. Bu çalışma, refleksoloji masaji farmakolojik olmayan bir semptom yönetimi tekniği olarak kullanılmasına ilişkin kanıtlar ekleyebilir.

Anahtar Sözcükler: Alopesi, kanser, kemoterapi, saç, refleksoloji

Address for Correspondence: Moloud RADFAR, Urmia University of Medical Sciences, Nursing, Urmia,

Received: 03.07.2019 İran

Accepted: 29.09.2019

Cite this article as: Ghavami H, Arjomand L, Radfar M, Khalkhali HR. Effects of Reflexology Massage on Hair Regrowth After Chemotherapy-induced Alopecia Among Women with Cancer: A Randomised Clinical Trial. Bezmialem Science 2020;8(3):215-21. 


\section{Introduction}

The roles of hair are protection, sensory functions, thermoregulation and sexual attractiveness (1). Although hair disorders or hair loss is not life-threatening; they negatively affect self-confidence, self-esteem and quality of life (QOL) (2). Due to significant improvement of modern chemotherapies, survival and prognosis also improved in majority of cancer entities; however, the number of related side effects also increases (3). Chemotherapy-induced alopecia (CIA) is a common unwanted effect related to anti-neoplastic agents. It generally starts at 1-3 weeks after the first chemotherapy cycle and is aggravated after subsequent cycles. Fortunately, patients usually recover from CIA spontaneously after 3-6 months. However, several patients experience permanent CIA, and many patients experience changes in hair colour, texture and growth rate even after hair regrowth (4). CIA can result in a negative body image, anxiety, depression, lower self-esteem and reduced sense of well-being and QOL (5,6). In addition, CIA negatively affects a patient's perception of appearance and sexuality. Moreover, patients feel deprived of their privacy because hair loss is interpreted as being associated with cancer (7). The incidence and severity of CIA are variable and associated with particular chemotherapeutic protocols. Approximately 65\%-85\% of chemotherapy patients experience some degree of alopecia. Overall, 47\%-58\% of female cancer survivors considered hair loss to be the most traumatic aspect of chemotherapy, and $8 \%$ of them fear that the cause of hair loss is decline from cancer treatment (5). No therapy for CIA has been established as a complete protection against all alopecic chemotherapies in human studies. Both scalp cooling and the immune modulating drug AS101 have reduced the severity of CIA in clinical trials (8).

Reflexology, which is defined as a holistic healing technique, is an ancient art involving various techniques and philosophical approaches (9) and considered to be a form of complementary and alternative medicine, which refers to treatments used either as an adjunct to or instead of conventional medical care (10). Reflexology defines reflexive zones both in the hands and feet, which are associated with glands, organs and other parts of the body (11). Reflexology, unlike other body therapies, is gentle and noninvasive. Only the feet and hands are considered. Therefore, it is an ideal modality for children or persons debilitated by cancer and cancer therapies (12).

Numerous studies have indicated that reflexology massage during and after cancer therapy can improve physical function, QOL and cancer-related symptoms, such as nausea and vomiting, fatigue, anxiety and pain, in cancer survivors (11,13-19). Because no study was published regarding the impact of reflexology on CIA, this randomised clinical trial aimed to evaluate the effect of reflexology massage on hair regrowth after CIA in women with cancer. We hypothesised that reflexology massage could enhance hair regrowth in the experimental group.

\section{Method}

\section{Ethical Considerations}

This study was approved by research ethics committee of the affiliated university. The participants were provided written information and allowed 3 days to consider their decision. All participants were informed that they were entitled to withdraw from the study at any time without any negative consequences. All participants provided their written informed consent to participate in the study. Furthermore, the researcher had received a reflexology massage certification from an international complementary and alternative medicine academy before this study.

\section{Design}

This was a randomised clinical trial conducted in women with cancer with full alopecia due to chemotherapy.

\section{Details of Power Calculations and Sample Size}

Because no study investigated the effects of reflexology massage on hair regrowth in the cancer population, appropriate information is unavailable for computation. However, considering the study of the effect of reflexology on the QOL in patients with breast cancer during chemotherapy (13), we chose role playing as a dimension of QOL, which seems to have a corresponding change with the subject; thus, the sample size is calculated using the following formula:

$$
\begin{gathered}
n=\frac{\left(s_{1}^{2}+s_{2}^{2}\right)^{2}\left(z_{1-\frac{\alpha}{2}}+z_{1-\beta}\right)^{2}}{\left(\bar{x}_{1}-\bar{x}_{2}\right)^{2}} \\
n=\frac{(1 / 96+0 / 84)^{2}(15 / 7+13 / 9)}{(70-57 / 5)^{2}}=29
\end{gathered}
$$

We concluded that recruitment of 30 patients for each group could give us $90 \%$ power to detect a difference in hair regrowth at an $\alpha$ level of 0.05 . Thus, we registered 60 patients (30 for each group).

\section{Patient Inclusion Criteria}

Patient inclusion criteria included women with cancer classified as stage I-III; patients who completed cancer primary treatment (surgery, chemotherapy and radiotherapy) 3 months prior; patients on one of these three chemotherapy drugs, namely adriamycin, cyclophosphamide and taxotere, because these more likely cause hair loss or thinning (20); patients with full alopecia; patients without any problem with their hands (especially with their fingers); patients without movement disorders; patients who did not receive any reflexology massage; and patients not using drugs to help hair regrowth or who underwent hair transplantation. Patients must be interested in attending reflexology educational and consultation sessions at least thrice a 
month for 3 months; patients must be adults (19-49 years) and able to read and write in Persian.

\section{Patient Exclusion Criteria}

Patient exclusion criteria included the use of other medications that could have any effect on hair growth, such as minoxidil, iron complements, oral contraceptive (OCP), anticoagulants, beta-blockers and antiepileptic drugs; patients with thyroid disease or severe infection; patients with history of surgery 3 months prior; or patients with malnutrition and iron deficiency anaemia; patients with metastatic cancer and with inoperable disease; patients with severe nausea, anorexia, or other diseases affecting health (e.g., arthritis and multiple sclerosis); patients who are unable for other reasons to continue participating in this research.

\section{Data Collection and Measures}

Data were obtained from the patient information and hair measurement forms. Couliss Vernier (Guanglu Caliper, 111-101 $\mathrm{HB}$, China) was used to measure hair regrowth. All patients in the experimental and control groups were instructed to complete the patient information questionnaire before the intervention. The patient information form was a researcher-made form.

\section{Clinical Interventions}

Initially, 86 patients were assessed for eligibility; of these, 60 women (according to the inclusion and exclusion criteria of the study) were randomised to the experimental or control group. An independent researcher randomised the patients by using random allocation cards using computer-generated random numbers. The allocator kept the original random allocation sequences in an inaccessible third place and worked with a copy. Instead, of the letters $\mathrm{A}$ and $\mathrm{B}$, codes $\mathrm{E}$ and $\mathrm{C}$ (experimental and control groups, respectively) were used to avoid further confusion. Subsequently, randomisation was continued until 30 samples were allocated for each group (CONSORT flow diagram).

\section{Clinical Interventions in the Experimental Group}

The patients in the experimental group received the following interventions: initially, their hands were washed with water and soap then dried with a towel. Subsequently, they received reflexology massage on points that are known as hair-growing points under the fingernail beds of the hands daily for the first 3 days for $15 \mathrm{~min}$. Because the points under the fingernail beds or Balayam (nail acupressure for hair growth) are strongly associated with scalp health and hair growth, as the nerve endings underneath each fingernail are believed to be connected directly to the hair roots (21).

The following instructions were given to the patients in the experimental group: their hands should be put together in front, with fingernails touching the fingernails of the other hand (elbows at an angle approximately $90^{\circ}$; thumbs straight out, resting on your index fingers). Their fingernails should be rubbed together vigorously (up and down in short, quick motions). This exercise should be performed at least 15 min thrice daily for 3 months.
Moreover, they received a reflexology check list and were instructed to check it when receiving reflexology massage. These check lists were controlled weekly by the researcher. In addition, the minimum and maximum lengths of the hair on the top of the head were measured monthly for 3 months after the beginning of intervention by using Couliss Vernier (Guanglu Caliper, 111$101 \mathrm{HB}$, China), such that its measuring instinct is between 0.01 $\mathrm{mm}$ and 0.001 inch.

\section{Clinical Intervention in the Control Group}

The patients in the control group only received their treatment as usual and routine health care, without receiving any massage.

\section{Statistical Analysis}

Statistical Package for Social Sciences ver.15 software was used for statistical analysis. Numbers were shown as percentage, mean and standard deviation for identifying characteristics of patients, and chi-squared, independent sample t-test and repeated measurement analysis of variance (ANOVA) test were used to evaluate statistical significance of socio-demographic data, disease characteristics and hair lengths between the experimental and control groups before and after the study. The results were

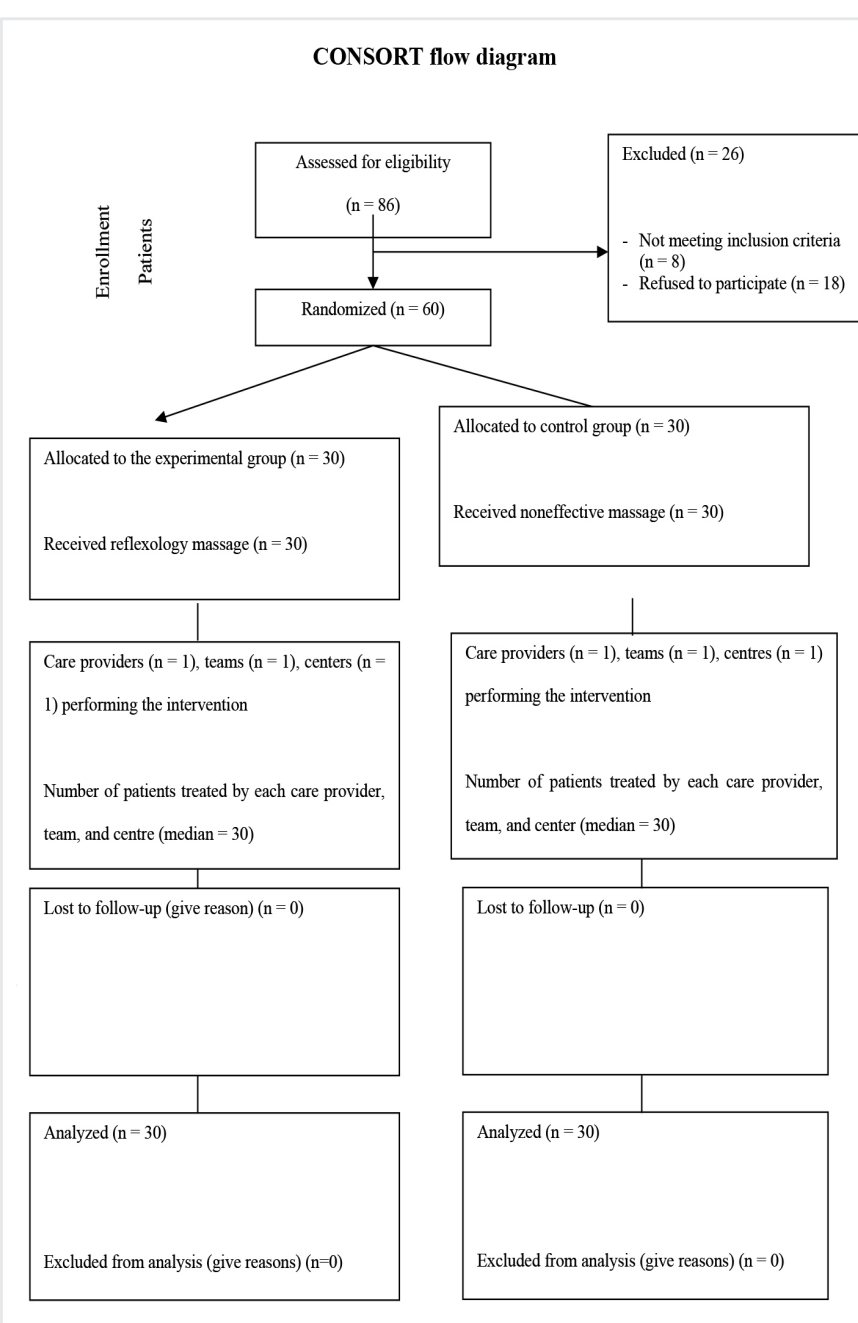

Figure 1. CONSORT flow diagram 
accepted at confidence level of $95 \%$ and statistical significance level of $\mathrm{p}<0.05$.

\section{Results}

\section{Demographic or Medical Characteristics}

Variables that might affect the study results, such as marital status; education level; use of adriamycin, cyclophosphamide and taxotere; employment status; income and age, were compared. No baseline differences existed between the two study groups for either demographic or medical characteristics and groups were similar together (Table 1).

\section{Hair Regrowth}

The study results showed better hair regrowth in the experimental group compared with the control group after the intervention (Tables 2-5).
All women in the two groups had full alopecia before the study. However, the result of repeated measurement ANOVA showed that the minimum hair regrowth rate between the two groups were statistically significant after the intervention $[\mathrm{F}(1$, 58) $=5.72 ; \mathrm{p}<0.001$; partial eta squared $=0.99$ ] (Table 3 ).

In addition, the result of repeated measurement ANOVA showed that the maximum hair regrowth rate between the two groups were statistically significant after the intervention $[\mathrm{F}(1$, $58]=8.52 ; \mathrm{p}<0.001 ;$ partial eta squared $=0.99)$ (Table 5).

Table 2 shows that the mean and standard deviation of the minimum hair regrowth rate were $1.85 \pm 0.52,12.45 \pm 1.72$, and $22.28 \pm 2.39$ in the experimental group and $1.32 \pm 0.46$, $11.44 \pm 1.46$, and $21.53 \pm 2.14$ in the control group in the first, second, and third months, respectively.

Table 3 shows the three effects tested (on the minimum hair regrowth rate):

\section{Table 1. Socio-demographic characteristics by group $(n=60)$}

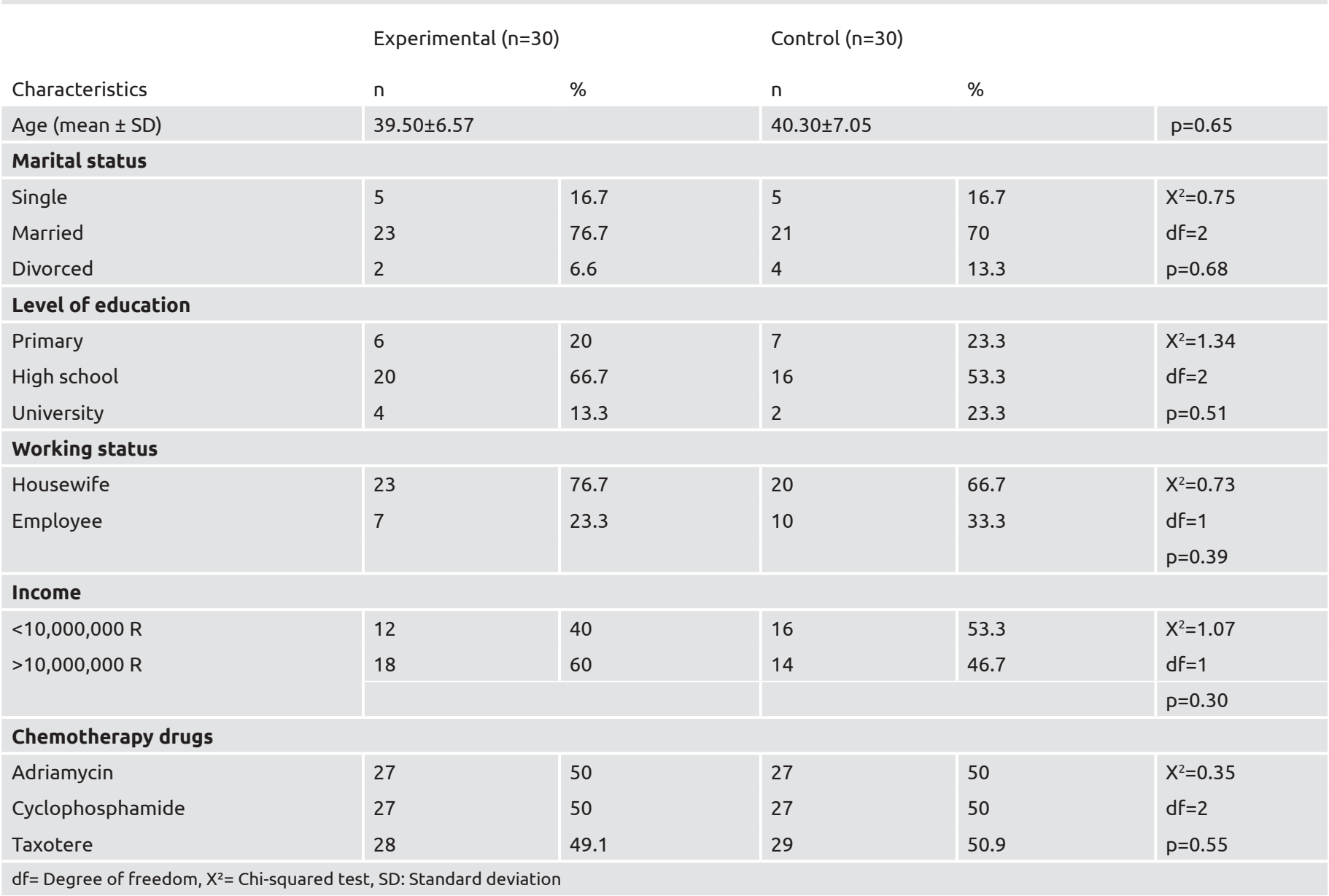

Table 2. Mean and standard deviation of minimum hair regrowth rate in both groups

\begin{tabular}{|l|l|l|l|}
\hline Group & \multicolumn{2}{l}{ Mean and standard deviation of minimum hair regrowth rate } & \\
\hline Month & First month & Second month & Third month \\
\hline Experimental & $1.85 \pm 0.52$ & $12.45 \pm 1.72$ & $22.28 \pm 2.39$ \\
\hline Control & $1.32 \pm 0.46$ & $11.44 \pm 1.46$ & $21.53 \pm 2.14$ \\
\hline
\end{tabular}


A. Interaction Between Time and Intervention: The statistical test indicates that the interaction between time and intervention during the first to third month is not significant on the mean of the minimum hair regrowth rate $(\mathrm{p}=0.61)$.

B. Main Effect of Time: A statistically significant difference was found in the minimum hair regrowth rate in the first to third month at different times $(\mathrm{p}<0.001)$.

C. Main Effect of Intervention: The main purpose of this study is to investigate this effect, and ANOVA results show that the mean of the minimum hair regrowth rate in the first to third month has a significant difference between the experimental and control groups $(\mathrm{p}<0.001)$ (Table 3$)$.

Table 4 shows that the mean and standard deviation of the maximum hair regrowth rate were $4.99 \pm 0.78,17.73 \pm 2.19$, and $29.93 \pm 3.08$ in the experimental group and $4.21 \pm 0.50$, $16.91 \pm 1.40$, and $28.24 \pm 2.22$ in the control group in the first, second, and third months, respectively.

Table 5 shows the three effects tested (on the maximum hair regrowth rate):
A. Interaction Between Time and Intervention: The statistical test indicates that the interaction between time and intervention in the first, second, and third months is not significant at the maximum hair regrowth rate $(\mathrm{p}=0.20)$.

B. Main Effect of Time: A statistically significant difference was found in the frequency of hair growth during the first to third month at different times $(\mathrm{p}<0.001)$.

C. Main Effect of Intervention: The main purpose of this study was to investigate this effect. The ANOVA results showed that the mean of the maximum hair regrowth rate during the first to third month had a significant difference between the experimental and control groups $(\mathrm{p}<0.001)$ (Table 5).

\section{Discussion}

This randomised controlled trial study aimed to determine the effects of reflexology massage on hair regrowth after CIA among women with cancer. Our study findings support our priori hypothesis that reflexology massage among women with cancer can improve hair regrowth after full alopecia.

\begin{tabular}{|c|c|c|c|c|c|c|}
\hline Minimum hair growth & $\begin{array}{l}\text { Total squared } \\
\text { error }\end{array}$ & $\begin{array}{l}\text { Degree of } \\
\text { freedom }\end{array}$ & $\begin{array}{l}\text { Mean squared } \\
\text { error }\end{array}$ & $F$ & $p$ value & $\begin{array}{l}\text { Partial eta } \\
\text { squared }\end{array}$ \\
\hline $\begin{array}{l}\text { Interaction of time with reflexology } \\
\text { intervention }\end{array}$ & 1.736 & 2 & 0.868 & 0.487 & 0.616 & 0.008 \\
\hline The main effect of intervention & $25,139.48$ & 1 & $25,139.48$ & 5.722 & $<0.001$ & 0.99 \\
\hline Component of intervention effect error & 254.83 & 58 & 4.39 & - & - & - \\
\hline
\end{tabular}

\begin{tabular}{|c|c|c|c|}
\hline Group & Mean and st & aximum hair regr & \\
\hline Month & First month & Second month & Third month \\
\hline Experimental & $4.99 \pm 0.78$ & $17.73 \pm 2.19$ & $29.93 \pm 3.08$ \\
\hline Control & $4.21 \pm 0.50$ & $16.91 \pm 1.40$ & $28.24 \pm 2.22$ \\
\hline
\end{tabular}

\begin{tabular}{|c|c|c|c|c|c|c|}
\hline Maximum hair growth & $\begin{array}{l}\text { Total squared } \\
\text { error }\end{array}$ & $\begin{array}{l}\text { Degree of } \\
\text { freedom }\end{array}$ & $\begin{array}{l}\text { Average squared } \\
\text { error }\end{array}$ & $\mathrm{F}$ & p value & $\begin{array}{l}\text { Partial eta } \\
\text { squared }\end{array}$ \\
\hline Main effect of time & $17,996.28$ & 2 & 8998.14 & 3621.24 & $<0.001$ & 0.98 \\
\hline $\begin{array}{l}\text { Interaction of time with reflexology } \\
\text { intervention }\end{array}$ & 8.01 & 2 & 4.00 & 1.61 & 0.20 & 0.02 \\
\hline Component of time effect error & 288.23 & 116 & 2.48 & - & & - \\
\hline Main effect of intervention & $52,074.41$ & 1 & $52,074.41$ & 8.522 & $<0.001$ & 0.99 \\
\hline Component of intervention effect error & 354.39 & 58 & 6.11 & - & - & - \\
\hline
\end{tabular}


The findings of this study were consistent with previous studies indicating that reflexology massage during and after cancer therapy can improve physical function, QOL and cancer-related symptoms, such as nausea and vomiting, fatigue, anxiety and pain in cancer survivors (11,13-19). For example, Quattrin et al. in 2006 aimed to examine the effectiveness of reflexology foot massage in hospitalised cancer patients undergoing second or third chemotherapy cycles. They concluded that reflexology foot massage can be considered a support treatment used in combination with traditional medical treatments and executed by an expert, qualified person to help cancer patients receiving chemotherapy feel better and also cope better with their disease (14).

Another study by Razi et al. determined the effect of reflexology on the QOL of patients with breast cancer who were receiving chemotherapy. Their results demonstrated considerable improvement in the different aspects of QOL in the reflexology group compared with the placebo and control groups (13).

In addition, Ben-Horin et al. (22) in 2017 conducted a retrospective study to evaluate the efficacy of acupuncture and reflexology protocol on chemotherapy-induced peripheral neuropathy (CIPN) in patients with breast cancer who were concomitantly treated with chemotherapy. Their study results demonstrated that a joint protocol of acupuncture and reflexology has a potential to improve symptoms of CIPN in patients with breast cancer (22).

In addition, our study is consistent with the study by Kang et al. (23) in 2018 who conducted a 3-year prospective cohort study. They concluded that permanent CIA is a common adverse event of breast cancer adjuvant cytotoxic chemotherapy. Clinicians should be aware of this distressing adverse event and develop supportive care strategies to counsel patients and minimise its impact on the QOL (23).

Although a qualitative study on Korean women with breast cancer reported that CIA never improved and remained visible several years after treatment $(23,24)$, the effects of different biological agents, such as minoxidil, AS101, cyclosporine A, parathyroid hormone (PTH) and PTH-related protein, have been evaluated in the management of CIA. Different results regarding the effectiveness of these approaches on hair regrowth after alopecia were obtained $(5,6,25)$.

\section{Study Limitations}

Our study has limitations, such as relatively small sample size, short study duration for hair regrowth, location of the programme, scheduling conflicts and transportation. The limitation of enrolling patients from two institutions also contributed to the small study population because many eligible patients could not participate in the reflexology massage programme due to location, transportation and conflicts in schedule.

\section{Conclusion}

The present study showed that the hair regrowth rate in women with cancer with CIA may improve by participating in reflexology massage programmes. Furthermore, this simple, effective, comfortable and low-cost programme for cancer survivors may apply to other types of alopecia. Additional research in reflexology massage along with using natural nutrient solutions on the scalp also may be beneficial. The study results may contribute to the growing body of knowledge supporting the feasibility and effectiveness of reflexology massage as a nonpharmacologic option for enhancing hair regrowth, body image and self-esteem in cancer survivors.

\section{Ethics}

Ethics Committee Approval: This study was approved by research ethics committee of the affiliated university.

Informed Consent: All participants were informed that they were entitled to withdraw from the study at any time without any negative consequences.

Peer-review: Externally peer reviewed.

\section{Authorship Contributions}

Surgical and Medical Practices: L.A., Concept: H.G., M.R., Design: H.G., H.R.K., Data Collection or Processing: L.A., H.R.K., Analysis or Interpretation: H.G., H.R.K., Literature Search: H.G., L.A., M.R., Writing: H.G., M.R.

Conflict of Interest: No conflict of interest was declared by the authors.

Financial Disclosure: The authors declared that this study received no financial support.

\section{References}

1. Alonso MR, Anesini C. Clinical evidence of increase in hair growth and decrease in hair loss without adverse reactions promoted by the commercial lotion ECOHAIR. Skin Pharmacol Physiol 2017;30:46-54.

2. Skrok A, Bednarczuk T, Skwarek A, Popow M, Rudnicka L, Olszewska M. The effect of parathyroid hormones on hair follicle physiology: implications for treatment of chemotherapy-induced alopecia. Skin Pharmacol Physiol 2015;28:213-25.

3. Schaffrin-Nabe D, Schmitz I, Josten-Nabe A, von Hehn U, Voigtmann R. The influence of various parameters on the success of sensor-controlled scalp cooling in preventing chemotherapy-induced alopecia. Oncol Res Treat 2015;38:489-95.

4. Shin H, Jo SJ, Kim DH, Kwon O, Myung SK. Efficacy of interventions for prevention of chemotherapy-induced alopecia: A systematic review and meta-analysis. Int J Cancer 2015;136:442-54.

5. Katikaneni R, Ponnapakkam T, Matsushita O, Sakon J, Gensure R. Treatment and prevention of chemotherapy-induced alopecia with PTH-CBD, a collagen-targeted parathyroid hormone analog, in a non-depilated mouse model. Anticancer Drugs 2014;25:30-8.

6. Koizumi T, Fukushima T, Gomi D, Kobayashi T, Sekiguchi N, Sakamoto A, et al. Alectinib-Induced Alopecia in a Patient with Anaplastic Lymphoma Kinase-Positive Non-Small Cell Lung Cancer. Case Rep Oncol 2016;9:212-5.

7. Trüeb RM. Chemotherapy-Induced Alopecia. Seminars in Cutaneous Medicine and Surgery 2009;1:11-4. 
8. Villasante AC, Herskovitz I, Mauro LM, Jimenez JJ. ChemotherapyInduced Alopecia. J Clin Investigat Dermatol 2014;2:8.

9. Öztürka R, Sevil Ü, Sargin A, Yücebilgin MS. The effects of reflexology on anxiety and pain in patients after abdominal hysterectomy: A randomised controlled trial. Complement Ther Med 2018;36:10712.

10. Imani N, Shams SA. Radfar M, Ghavami H, Khalkhali HR. Effect of applying reflexology massage on nitroglycerin-induced migraine-type headache: A placebo-controlled clinical trial. Agri 2018;30:116-22.

11. Icke S, Genc R. Effect of Reflexology on Infantile Colic. J Altern Complement Med 2018;24:584-8.

12. Rooney D. Reflexology/Therapeutic Massage. Integr Cancer Ther 2006;5:53-5.

13. Shadan P, Haghighat S, Jarban M, Parsa Yekta Z, Agha Hosseini F. The effect of reflexology on quality of life of breast cancer patients during chemotherapy. Iranian Quarterly Journal of Breast Disease 2013;1:23-34.

14. Quattrin R, Zanini A, Buchini S, Turello D, Annunziata MA, Vidotti C, et al. Use of reflexology foot massage to reduce anxiety in hospitalized cancer patients in chemotherapy treatment: methodology and outcomes. J Nurs Manag 2006;14:96-105.

15. Wilkinson S, Lockhart K, Gambles M, Storey L. Reflexology for symptom relief in patients with cancer. Cancer Nurs 2008;315:35460.

16. Stephenson NL, Weinrich SP, Tavakoli AS. The effects of foot reflexology on anxiety and pain in patients with breast and lung cancer. Oncol Nurs Forum 2000;27:67-72.
17. Stephenson N, Dalton JA, Carlson J. The effect of foot reflexology on pain in patients with metastatic cancer. Appl Nurs Res 2003;16:2846.

18. Wyatt G, Sikorskii A, Rahbar MH, Victorson D, You M. Healthrelated quality-of-life outcomes: a reflexology trial with patients with advanced-stage breast cancer. Oncol Nurs Forum 2012;39:568-77.

19. Ketut N. Effect of foot massage on nausea, vomiting and retching in women with cervical cancer undergoing chemothrapy, in Bali, Indonesia. Nurse Media Journal of Nursing 2012;2:467-81.

20. Komen MMC, Smorenburg CH, van den Hurk CJG, Nortier JWR. Factors Influensing the effectiveness of scalp cooling in the prevention of chemotherapy-induced alopecia. Oncologist 2013;18:885-91.

21. http://www.shealthtips.com/exercise/nail-rubbing-exercise-effectivetechnique-for-hair-growth/ (Access date: 6/21/2019).

22. Ben-Horin I, Kahan P, Ryvo L, Inbar M, Lev-Ari S, Geva R. Acupuncture and Reflexology for Chemotherapy-Induced Peripheral Neuropathy in Breast Cancer. Integr Cancer Ther 2017;16:258-62.

23. Kang D, Kim IR, Choi EK, Im YH, Park YH, Ahn JS, et al. Permanent Chemotherapy-Induced Alopecia in Patients with Breast Cancer: A 3-Year Prospective Cohort Study. Oncologist 2019;24:414-20.

24. Kim IR, Cho J, Choi EK, Kwon IG, Sung YH, Lee JE, et al. Perception, attitudes, preparedness and experience of chemotherapyinduced alopecia among breast cancer patients: A qualitative study. Asian Pac J Cancer Prev 2012;13:1383-8.

25. Can G, Yildiz M, Özdemir EE. Supportive care for chemotherapy induced alopecia: challenges and solutions. Clinical Research in Infectious Diseases 2017;4:1048. 